\title{
Topografen J. N. Schmidt.
}

\section{Af August F. Schmidt.}

Blandt Sønderjyllands Topografer og Lokalhistorikere indtager $\mathrm{J}$ es $\mathrm{N}$ ielse $\mathrm{n} \mathrm{S} \mathrm{ch} \mathrm{mid} \mathrm{t} \mathrm{en} \mathrm{såre} \mathrm{smuk} \mathrm{Plads,} \mathrm{idet}$ han i $\sin$ korte Levetid fik udrettet et forbløffende stort og godt Arbejde til Oplysning om Fortidsforhold i Landet Syd for Kongeaaen. Han blev født i 1827 i Kl i ple v, hvor hans Forældre, J. J. S c h midt og B. M. S ch m idt, f. Thullesen, boec̀e. Tidligt må Jes Schmidt have udvist historiske Interesser og Anlæg - som 15-årig Knøs overværede han i 1842 stærkt optaget Udgravningen af $\mathrm{M} ø \mathrm{l} \mathrm{h} ø \mathrm{j}$ Nordvest for $\mathrm{U} \mathrm{g} \mathrm{e}^{1}$ ) - og det var da ret naturligt, at han blev holdt til Bogen. Han gennemgik derfor Seminarieuddannelsen på Tønder Seminarium og ansattes, efter at have taget Lærereksamen, som Lærer $\mathrm{i}$ de to smá Landsbyer Tods bøl og Gås kær i B jol d e r u p Sogn. Det var meget almindeligt førhen, at en Lærer underviste Børnene i to Byer, tre Dage ugentligt hvert Sted. Således har det nok også været her.

Ved Selvsyn fik Jes N. Schmidt gennem Barndomsårene og den første Ungdom et godt Kendskab til Landet mellem Kliplev og Vesterhavet, en Viden, han fuldt forstod at udnytte. Det lykkedes ham endog efterhånden at få berejst næsten hele Sønderjylland, og da han havde et udviklet Blik for landskabelige Ejendommeligheder, havde han til sin litterære Virksomhed stor Gavn af sine Studier i Marken.

Vi ser det straks $i$ hans første Afhandling: "O l ger d ige o g Frisergrændsen« (Antiquarisk Tidsskrift 1846-48, 274-79), hvor han giver en på Selvsyn grundet Skildring af det gamle Befæstningsværk: O 11 e mers i get, og fortśteter her, hvad Nicolai O u t z e tre Artier tidligere havde skrevet om dette ejendommelige Forsvarsværk i sit Prisskrift: "Die dänische Sprache im Schleswigschen« (1819), S. 18, - det før-

\footnotetext{
1) Antiquarisk Tidsskrift 1849-51 (1852), 54.
} 
ste Sted, hvor der er fremført Betragtninger over Digets Hensigt. Outzen mente, det var opført som Værn mod Friserne. J. N. Schmidts Skildring af den sønderjydske Folkevold har sin sserlige Værerdi ved de gode Oplysninger, han meddeler om Voldens Udstrækning m. v., - et Emne, hvis Behandling han på fortrinlig Måde supplerede i Antiquarisk Tidsskrift 1849-51, 55. Adskıllige selvstændige Betragtninger om Frisergrænsen (belyst ud fra Stednavnetyper ${ }^{1}$ ) meddeler Schmidt ogsaa i sin første Afhandling, hvor han på hæderfuld Vis fortsætter Studiet af Ollemersdiget, som det først o. 1922 skulde lykkes Vilhel m l a C o u r at give den rigtige Forklaring på, idet la Cour påviser, at Diget nøje slutter sig til den jydske Besiddelse mod Syd, og spærrer Vejen mellem Jyder og Angler. Hvad Danevirke i en senere Tid var imellem Danskere og Tyskere, måtte Ollemersdiget mange Århundreder i Forvejen have været mellem de stridende Småstammer Angler og Jyder. ${ }^{2}$ ) - I 1924 tog nærv. Forfatter de jydske Folkevolde op til Behandling $i$ en Oversigt i Samlinger til jydsk Historie og Topografi, 4. Rk., IV. Bd. (1922-24, udk. 1925), hvor Ollemersdiget er omtalt S. 448$\left.50 .{ }^{3}\right)$ Her blev for første Gang - efter Anvisning af S vend A a kjær - Tolkningen af Voldnavnet udfra Ordet Oldemoder givet, hvorved Navnet Oldemorsdiget skulde betyde "det ældgamle Dige«, en Tolkning, Dr. la Cour accepterer i Sønderjyllands Historie I (1931), 154; jfr. også Sønderjydske Stednavne III (1934), 660. I Slutningen af 1920'erne kom der særlig Fart i Studiet af Folkevolden. H. P. Jørgen se n, Uge, gav i Sønderjydske Aarbøger 1928, 132 ff., et fortræffeligt Bidrag til Litteraturen om Diget. Hugo Matthiesen har i sin Bog: Hærvejen (1930), 142 ff., 182, leveret vigtige Oplysninger om Emnet, og Dr. la Cour har så haft det sidste Ord i Sagen, idet han i sit store Arbejde om Sønderjyllands ældste Historie har meddelt alle nødvendige Oplysninger om Ollemersdiget og

1) Jfr. Vilh. la Cour i Sønderjyllands Historie I (1931), 322 ff.

$\left.{ }^{2}\right)$ Vilh. la Cour: Geschichte des schleswigschen Volkes I (1923), 56.

3) Denne Skildring blev optrykt i Sønderjydsk Maanedsskrift 1. 5. 1925, suppleret med nye Oplysninger af $\mathrm{H}$. Lausten Thomsen. 
dets Betydning. ${ }^{1}$ ) Man tør vist nu sige, at den gamle Folkevold i J. N. Schmidts Hjemstavn er tilstrækkelig undersøgt, hvorfor Arkæologerne bedes underkaste de øvrige Folkevolde i Jylland lige så grundig en Behandling som den, Danevirkes gamle Nabo i Nord lykkeligvis har været udsat for.

I Forbindelse med Omtalen af Schmidts Arbejde om Ollenersuliget vil det være hensigtsmæssigt at nævne hans anclen Afhandling om hans Barndomsegn, nemlig Bidraget i Antiquarisk Tidsskrift 1849-51, 47-57, der er underskrevet: "Tinglev i Marts 1850 « og handler om Urne hoved-Eg ne n. Udfra en efter Tidsforholdene omfattende Viden om Sønderjyllands gamle Historie, om Tingsteder, Oldtidsminder og Topografi -suppleret med grundigt Selvsyn af Egnen omkring Urnehoved - meddeler J. N. Schmidt en Rakke Iagttagelser om den minderige Egn Vest for Åbenrå. Slet ikke så få Enkeltheder om Oldhøje og Oldfund findes $i$ hans Fremstilling, hvis mest virkende Afsnit er det, der handler om Stedsbestemmelsen af Sønderjyllands gamle Tingsted Urne hoved, som Forf, henlægger til Løg pold i Bjolderup Sogn. Denne Bestemmelse er senere blevet godtaget af Svend Aakjær og Vilh. la Co u r, men synes at være rokket, efter at man i Sønderjydske Stednavne IV (1936), 320 ser, at Logpold ikke betyder nfredlyst Sted, Tingsted«, men må afledes af Plantenavnet $\mathrm{L} ø \mathbf{g}$. Bemærk også Tolkningen af Ur n e h oved i Sønderjydske Stednavne IV, 353, hvor det oplyses, at det gamle Tingsteds Plads ikke er påvist med Sikkerhed.

Man vil forstaa, at det også i Afhandlingen "Urnehovedegnen i Slesvig« er centrale Problemer, Schmidt med Sans for det væsentlige kaster sig over og yder et værdifuldt Bidrag til Løsningen af. Han har ledsaget sin Afhandling med et fortræffeligt af ham selv tegnet $\mathrm{K}$ or t over Sognene Tinglev, Uge, Bjolderup og til Dels Hjordkær (Tab. III i Antiq. Tdskr. 1849-51). Schmidt havde nemlig særlig gode Evner som K or t t e g-

1) Sønderjyllands IIistorie I (1931), 153-157, 505 (sidstnævnte Sted udførlige Litteraturhenvisninger). 
ner, og han har i Virkeligheden ydet en ikke uænseværdig Indisats som Kartograf. Denne Virksomhed hænger sammen med hans geografiske Viden og Interesser, et Område, han på en ret underholdende Måde demonstrerede sine Kundskaber i med et Par Anmeldelser, han skrev, kort efter at han i Krigstiden 1848 - fordrevet fra $\sin$ Lærerstilling i Bjolderup Sogn - var kommet til København, hvor han som Flygtning opholdt sig 1 1/2 Aar. Han begyndte her som Recensent af geografiske Lærebøger. Den første af hans Anmeldelser i hin Retning er dagtegnet den 1. September 1848 og er en indgående $\mathbf{i}$ vel oplagt Form skrevet Kritik af den geografiske Forfatter P. C. Friedenreichs "Grundrids af den topiske Jord-Beskrivelse til Skolebrug “. Friedenreich svarede på Schmidts Kritik, og Schmidt svarede så Friedenreich i et vel tourneret Svar. $\left.{ }^{1}\right)$ Umiddelbart efter Omtalen af Friedenreichs Bog anmelder Schmidt J. C. L. P lenges "Geografi for Borger- og Almue-Skoler«. Anmeldelsen er underskrevet København d. 28. Sept. 1848. ${ }^{2}$ ) I begge Anmeldelser åbenbarer J. N. Schmidt sig som et kritisk Talent, i Besiddelse af en Viden om den matematiske Geografi, der må anses for at have ligget langt over Jevnmålet af, hvad en Lærer i 1840'erne burde kende om dette ret vanskelige Fag. Også til den almindelige politiske Geografi havde Schmidt et betydeligt Kendskab, hvad især hans mange Rettelser til Plenges Lærebog giver Beviser på. Man får igennem de to kritiske Anmeldelser lidt Forståelse af J. N. Schmidts kartografiske Evner, som hans senere Forfatterskab så fortrinlig understøttes af.

Det blev dog ikke som Kritiker, Schmidt brugte sin Tirl i København. Han gav sig ihærdigt i Gang med at læse alt, hvad han kunde få fat $\mathrm{i}$ om Sønderjyllands Historie, og med stor Flid ekscerperede han alle trykte Skrifter, han på de store kø-

1) Schmidts Anmeldelse findes trykt i Maanedsskrift og Repertorium for Almue-Skolelærere IX (1848), S. 347-51. Friedenreichs Svar findes smsts., S. 386-90. Schmidts Svar herpaa ses S. 436-39. $420-23$.

$\left.{ }^{2}\right)$ Trykt i Maanedsskrift og Repertorium IX (1848), S. 403-06, 
benhavnske Biblioteker kunde låne om sit Hjemland. Han erhvervede sig snart så megen Viden om Sønderjyllands Historie $i$ det hele taget i det 12.-14. Arhundrede, at han ud fra denne turde udarbejde et Landk ort over Slesvig i V aldemarernes Tid. Dette Kort, der var hans forste Arbejde ${ }^{1}$; i kartografisk Retning, blev bekostet udgivet af Det kgl. nordiske Oldskrift-Selskab (af hvilket Schmidt blev optaget som Medlem) og fremkom som Lithografi hos Bærentzen \& Comp. i 1850 (in $\left.4^{\circ}\right)$. Udgangspunktet for Kortet er Valdemar II Sejrs Jordebog 1231, Johan Mejers Kort, der angives at være fra 1240, og andre samtidige Dokumenter. Det vanskelige Arbejde, Schmidt her havde udført, fandt han selv senere Lejlighed til at fremkomme med nogle Rettelser til, isaer angående Kortafsnittet over Frisland og Sydgrænsen,") men trods dette aftvinger Kortarbejdet Respekt for den unge, landflygtige Lærer. Denne bliver ikke mindre, naar vi betragtar hans næste kartografisk-historiske Arbejde, den udførlige Aihandling: „Undersøgelser angaaende Troværdigheden af Johan Mejers Kort over Nordfrisland 1240 hos Danckwerth og Landets Tilstand i ældre Tid ${ }^{3}$ ) I denne Undersegelse, hvori Jes Schmidts kritiske Evne og sunde Opfattelse i høj Grad udmærker sig, er givet en stor Række Detailoplysninger om Frisland i gammel Tid. Hensigten med Arbejdet er at begrunde Udarbejdelsen af det kritiske Kort over det gamle Nordfrisland, som Schmidt udarbejdede som en Revision af de af $\mathrm{J}$ oh a $\mathrm{n}$ Mejer i 1652 udgivne tvende Kort over sammes Nord- og Syddel ved Aret 1240. Det var i Virkeligheden et forbloffencle godt Kendskab, J. N. Schmidt havde til Frislands Historie og Geografi, og at han har underkastet hele den kartografiske Overlevering om Vestkysten af Slesvig-Holsten en endda meget

1) Det er tegnet før det ovenfor omtalte Kort over Urnehovedegnen.

$\left.{ }^{2}\right)$ Berlingske Tidende 11. 6. 1850. Jfr. Nordisk Telegraph II, S. 1111. .... Worsaaes Breve (udg. 1930 af (Clément), 30.

${ }^{3}$ ) Annaler for nordisk Oldkyndighed 1851, 161-21; plus Tab. I. 
grundig og selvstændig Undersøgelse, erfarer man atter og atter $i$ hans omfangsrige Fremstilling. Der er ingen Grund til her i Enkeltheder at referere Schmidts Frislandsarbejde eller gã nøjere ind på hans Vurdering af Troværdigheden af Johaı Mejers Kort, især da man så også burde gøre udførligt Rede for Peter La u idsens store Afhandling i Historisk Tidsskrift 6. Rk. I. Bd. (1887-88) om Johan Mejers Liv og Virksomhed. ${ }^{1}$ ) I adskillige Tilfælde giver Lauridsen Schmidt Ret ,i hans Synspunkter om Mejers Kort (således S. 373 i anf. Afh.), medens han andetsteds (f. Eks. S. 378) er af en anden An'skuelse end sin Forgænger i Studiet af Sønderjyllands Kartografihistorie. Således er Lauridsen (S. 393) imod enhver Revision af Mejers Vestkystkort, da han mener, det er uvidenskabeligt at ændre direkte ved det. Schmidt mener deiimod - som alt antydet - at det er muligt udfra tilstrækkelige historiske og geologiske Kundskaber at revidere hint Kort, og derved give det så vidt muligt rigtige Indtryk af Sønderjyllands Vestkyst, bl. a. før den store Manddrenkelse 1362. ${ }^{2}$ )

Jes Nielsen Schmidts Hovedværk er dog hans Sønderjyllandstopografi: "Slesvig's Land og Folk, physisk, topographisk og localhistorisk fremstillet, en Topographi for Dannede af alle Samfundsklasseru. Dette Arbejde udkom i Årene 1851-52 i fem Hefter og er ialt på XII plus 390 Sider (in 80). Det blev trykt hos Fr. Fis ch er i Ábenrå og blev forelagt af denne Danskhedens Forkæmper sammen med J. N. Schmidt selv. ${ }^{3}$ ) Han samlede $i$ alt væsentligt Stoffet til sin Topografi i Kobenhavnstiden, hvor han mødte stor Beredvillighed fra de offentlige Bibliotekers Side. Over 100 Bind blev gennempløjet,

1) P. Lauridsen begyndte også sit udmærkede Forfatterskab som Kartografhistoriker. Jfr. Lauridsens korte Biografi af J. N. Schmidt i Dansk biografisk Lexikon XV (1901), 222. Erslews Forfatter-Lexicon, Supplement III, 77 .

$\left.{ }^{2}\right)$ Om Frislands ældre Historie se iøvrigt Vilh. Ia Cours storartede Fremstilling i Sønderjyllands Historie I, 3̈14 ff, 519 f.

3) En 2. Udgave udkom 1861 pả Boghandler F. Wollikes Forlag i København. Denne Udgave har et nyt Titelblad (se Dagbladet 19. 10. 1861; Aalborgposten 16. 11. 1861, korte Anmeldelser). 
inden Udarbejdelsen af "Slesvigs Land og Folk « tog $\sin B e-$ gyndelse. Også dette Arbejde har nydt godt af Forfatterens Førstehåndskendskab til Sønderjyllands Egne. Værket er anlagt som en Håndbog og udfyldte ved sin Fremkomst i 1851-52 en tom Plads i vor topografiske Litteratur. Det fik sin værdige Afløser i 1. Udgave af J. P. Traps "Danmark", hvis Sønderjyllandsbind I-II så Lyset i 1864 .

I forste Afdeling af "Slesvigs Land og Folk" behandles Landets Physiographi (Østranden, Højderyggen, Vestskråningen, Vestsletten, Øerne), ${ }^{1}$ ) H y d rographi (Havet: Kicler Bugt, Lille Belt, Vesterhavet, rindende Vande, Indsøer, Sumpe, Kær, Moser m. m.), K li mat o pog ra ph i (Luften), hvorefter man $i$ anden Afdeling hører om Folket. Her er Kapitler om Godsejerstanden, Embedsmandsstanden, Borgerstanden og de lavere Klasser. Endvidere omtales S p rog e n e: Dansk, Frisisk, Plattysk samt Nationaliteten. Tredie Afdeling skildrer de $æ 1 \mathrm{dste}$ Ind delinger af Landet, Feudalvæsenet, Slesvig tredelt 1582-1721, Slesvig forenet 1721-1852, den kommunale Inddeling, Amter og Landskaber, Købstæder, de adelige Godser, den kirkelige Inddeling $\mathrm{m}$. v.

Så kommer den specielle Topografi. Her bliver hver Købstad og hvert Sogn kort omtalt. Landområdet er lige fra Kolding Fjord og Kongeåen og ned til Ejderen, ligesom Femern $\varnothing$ og Amt også er medinddraget i Beskrivelsen, s ̊̊ Schmidt har ikke sparet sig nogen Ulejlighed. Til Udarbejdelsen af de enkelte Købstæders og Sognes Topografi og Historie har han haft god Nytte af August Baggesens Værk: "Den danske Stat" (1840), en statistisk-historisk Fremstilling, ligesom han har kunnet udnytte slet ikke så liclt af det stedshistoriske Stof, der findes i VII. Bind af Erik Po:1toppidans (og H. de Hoffmanns) "Danske Atlas" (1781). Selv om Schmidts meget kortfattede Sogneskildringer snart blev overfløjet af, hvad Trap kunde fremmøde med i sin Dallmarkstopografi, findes der stadig en og anden Bemærkning af

1) Se den sindrige Oversigtsfremstilling S. 27-28 i Topografien. 
Værdi i de topografiske Småstykker, $\left.{ }^{1}\right)$ der samlede er en stor Flidspræstation, men det er naturligvis i de indledende tre almindelige Dele, man $i$ vor Tid skal finde de Oplysninger af varig Værdi, som Schmidts Bog er forlenet med; thi det forholder sig således, at medens Befolkningstilstande, Statistik o. lign. snart forældes i en Håndbogsfremstilling, så har Oplysninger om Sæder og Skikke, Befolkningens indre Tilstand $\mathrm{m}$. v. uafbrudt deres Betydning, og derfor vil "Slesvigs Land og Folk « stadig være en værdifuld Samlingsbog at slå op i. Man kan således fremhæve, hvad Schmidt $S$. 73 skriver om de bevægede Retsforhold i Sønderjylland. Man havde mange forskellige Love, såsom den jy d s e Lov fra 1240, D a nske Lov af 1683, den lybske Ret, Kobstadsretter, den gamle frisiske Landret på Føhr, Spadelandretten i Marsken, den danske Søret, Forordninger, og endelig $S æ d v a n e n$, der også $i$ visse Tilfælde gjaldt som Ret. ${ }^{2}$ Mest værdifulde er Afsnittene om $\mathrm{Håndværk}$ og A g e r b r ug, K væg a v l og Markeder, Husflid, K n i pling, Kådnere og Indsiddere, idet man deri træffer på gode Førstehåndsoplysninger om den gamle sønderjydske Almuekultur. Det må erindres, at Schmidts Fremstilling er skrevet adskillige $\AA$ r, for H. F. Feil berg s Bog »Fra Heder» udkom (1863), så Feilberg har sikkert ikke uden Udbytte læst Schmidts Afsnit om Livet i de sønderjydske Landsbyer, og nu så mange År efter kan man stadig bruge Oplysninger fra "Slesvigs Land og Folk" til at udfylde, hvad der mangler hos Feilberg og i yngre Folkemindeoptegnelser (f. Eks. om Husflid hos Hedebønderne). ${ }^{3}$ )

J. N. Schmidts Topografi udmærker sig ved Simpelhed og Klarhed i Ordningen og var for sin Tid så fuldstændig, som Emnet udkrævede det, uden at indlade sig på trættende En-

1) Eksempelvis kan nævnes Oplysningerne om Blåbærplukning, Markeder, Torvelader $m . M$ i $\mathrm{H}$ a n ved Sogn (S. $259 \mathrm{f}$.).

$\left.{ }^{2}\right)$ Jfr. Flyve-Posten 19. 11. 1851.

3) Se Sydslesvig I (uilg. 1933 af Gunnar Knudsen og Knud Kretzschmer), 138 f. 
keltheder. Selv om Bogen blev udarbejdet i alt vaesentligt under Treårskrigen, støder man i den ikke noget Sted på en eneste Yttring af Had eller Bitterhed imod noget som helst Parti i eller udenfor Sønderjylland. ${ }^{1}$ ) Denne Fornægtelse af at give sikkert stærke indre Følelser Udbrud, taler til Ere for Jes Schmidt, der følte det som sin Opgave at være en fordomsfri og redelig Historiker, hvad da også hele hans Forfatterskab bærer Vidne om, at han var.

J. N. Schmidt kunde også gøre Vers. I "Dannevirke« 11. Årg. 1849, Nr. 112, 13. 6. har han fået offentliggjort et Digt på 6 Vers: "Aftenen den 5te Juni 1849«, en Hyldest til deu frie Forfatning. Næppe en Måned senere, den 12. 7. 1849, fik hall et Digt på 5 Vers frem i "Dannevirke«, 12. Årg. Nr. 10: Et Mindekvad om Fredericiaslaget den 6. Juli 1849. Begge Digtene er ganske gode og viser, at Schmidt var en frihedsbegejstret og nationalsindet Mand.

Den 1. September 1851 blev J. N. Schmidt ansat som 8te Lærer ved Domskolen i Slesvig. Hernede arbejdede han flittigt med Afslutningen af sin Topografi, hvis Forord er dagtegnet den 15. Juli 1852. Man nærede med Rette betydelige Forventninger til den da 25årige Lærers litterære Virksomhed. Forbausende meget havde han nået at få gennemforsket og behandlet, så det kunde offentliggøres i Tidsskrifter og i Bogform .... En lang og udbytterig Arbejdsdag lå foran den begavede Mand. Men de misundelige Guder vilde det anderledes. Allerede i Marts 1852 måtte han opgive sin Lærerstil. ling; Foråret og Sommeren hensled han, kæmpende med en snigende Tuberkulose. Han havde den Glæde at opleve at se $\sin$ Topografi færdigudkommet, men han nåede ikke at meddele en kort Fremstilling af sit Levnedsløb til Slesvig Domskoles Program, hvad han til det sidste havde onsket at

1) Et Forhold, den engelske Loktor i Kobenhavn, senere Professor George $S$ tephens fremhaver i sin rosende Anmelrelse af Schmidts Bog $i$ The Morning Chronicle 26. 12. 1851 (jfr. Fadrelandet Nr. 1, 1852). 
kunne. ${ }^{\text {) }}$ Den 1. September 1852 døde Jes Nielsen Schmidt i Tinglev, 25 År gammel. Han fik sin Grav på Tinglev Kirkegård ved det nordøstlige Hjørne af Kirken. Her hviler ogsaa hans Forældre. ${ }^{2}$ ) Schmidts Grav var indtil for en Del Ar siden forsømt, men så henstillede Fredningsnævnet til Menighedsrådet om at vedligeholde Graven. Det har Rådet ogs̊̊ siden gjort. Gravstedet blev f. Eks, i Foråret 1937 meget smukt beplantet med Roser, og det blev ved den Lejlighed også bestemt, at Mindesmærkets Indskrift skulde fornyes.") så i Fremtiden kan man have den Glæde at vide, at J. N. Schmidts Grav er i værdig og smuk Stand. Måske da også en og anden følsom Sjæl kan finde Opbyggelse $i$ at dvæle en Stund ved den unge Historikers sidste Lejested.

En stor Sorg var J. N. Schmidts tidlige Bortgang. Dødens Greb var her så brutalt. En Mand som han hører til de uundværlige $i$ en Folkestamme, hvis Nationalitet er truet. Han viste næsten til Overmål, hvad han duede til. En skøn og hæderfuld Plads $\mathrm{i}$ den sønderjydske Historieskrivning vilde han være kommet til at have udfyldt, hvis han var blevet tilmaalt et passende Antal Leveår.

Men sådan gik det altså ikke. Hans Liv blev et Arbejdets Eventyr, et Digt til Danmarks Ere. Har vi trøstet os herved, undlader man alligevel ikke at tænke på Jeppe A a k jærs Mindevers over Vennen $\mathrm{N}$ iels Bransager:

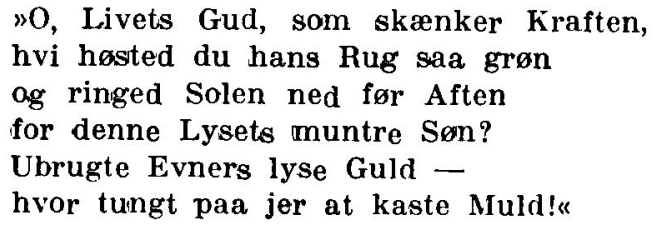

5. Juni 1937.

A ugust F. Sch midt.

1) Roktor J. P. A. Jungclaussens Maddelelse i "Beiträge zur neuesten Geschichte der Domschule« (Schleswig 1852), S. 22, der karakteriserer Schmidt som en rigtbegavet Mand.

$\left.{ }^{2}\right)$ Th. P. i Hejmdal 1. 6. 1937.

3) Hejmdal 3. 6. 1937 . 